Lenka Hvolkova,

Ph.D., Assistant Professor, Matej Bel University, Slovakia

Ladislav Klement,

Ph.D., Assistant Professor, Matej Bel University, Slovakia

\title{
MANAGEMENT OF INNOVATION DEVELOPMENT IN THE SLOVAK REPUBLIC: CRITICAL EVALUATION OF THE INVESTMENT AID SYSTEM.
}

Abstract. Since 2002, the Slovak government have been using the system of investment aid for enterprises. However, the economy of the Slovak Republic characterized by differences among regions. Therefore, in March 2018, the Slovak government modified the system of investment aid to mitigate the differences among the regions. The main aim of the paper is to examine whether investment aid in Slovakia has served its purpose and was channelled to disadvantaged Slovak areas. The objects of the research are particular investment projects supported by the state investment aid in the observed period. The subjects of study are the selected forms of investment aid provided in the Slovak republic. The paper analyses the amount and structure of the provided investment aid in the Slovak Republic during the period 2002-2018. The secondary data on business entities, which received investment aid was obtained from the Ministry of Economy of the Slovak Republic. An additional source of information is data from the Statistical Office of the Slovak Republic about the rate of unemployment and GDP per capita in the Slovak regions. Descriptive statistics and comparison analyse the obtained data to evaluate the total provided investment aid. The authors work with three research questions. The first concerned the uniformity of investment aid provision during the years 20022018. The second focused on verifying the proportionality of the covered costs to the newly created jobs. Finally, the authors test the primary mission of investment aid, reducing regional disparities (based on the allocation of investment aid to regions of the Slovak Republic). There were identified evident differences in the total amount of provided investment aid in particular years. The analysis confirms that the costs for one newly created job in particular Slovak regions were quite different. There were regions where the subsidies for one new job were three times higher than in others. During the analysed period, the majority (56\%) of investments were realised in regions with a lower rate of unemployment compared to the average price in Slovakia. The aid in these regions was achieved, with $75 \%$ of the total amount of investment aid. The results of the analysis confirm that investment aid in Slovakia is still not focused on the support of less developed regions.

Keywords: investment aid, Slovak Republic, state support, regions, unemployment rate.

Introduction. As many economic topics, the issue of providing of investment aid is widely discussed due to contradictory opinions among politics as well as professionals. Investment aid supporters advocate it as a competitive advantage for the country and consider it as an effective way to attract and support significant foreign and domestic investments. On the other hand, opponents criticize its use, mainly because of the distortion of natural competition by favouring selected (supported) enterprises at the expense of other entrepreneurs and the public. Leaning towards the side of supporters or opponents is not easy. Several authors highlight the various indicators that are supposed to shift the scale to one or the other side. (Collie, 2005; Friederiszick et al., 2008; Holscher et al., 2017) When processing this article, the effectiveness was selected as the main criterion measured through selected economic and social indicators. The paper examines the use of investment aid in Slovakia for the period 2002-2018 to assess how effective it was spent. The continuity of regional disparities in Slovakia, where the Bratislava region is developing more rapidly than the remaining areas of Slovakia, also underlines the importance of the topic. The local investment aid is one of the leading government's tools to primarily mitigate and, at best, prevent the widening differences in the socio-economic development of the country's regions.

Literature Review. State aid shall be understood in a broad sense. Mynarzova (2014) presents it as any directly or indirectly granted aid, which is financed by state resources and provided by the state or through a body acting based on delegated competence. This definition can be extended by the view of the

Cite as: Hvolkova, L., Klement, L. (2019). Management of Innovation Development in the Slovak Republic: Critical Evaluation of the Investment Aid System. Marketing and Management of Innovations, 1, 26-39. http://doi.org/10.21272/mmi.2020.1-02 

Investment Aid System

recipient of the aid. Tetrevova et al. (2011) pointed out that the concept of state aid is «any economic advantage granted to one or more undertakings which would not normally have been acquired by those undertakings in the course of their business». Generally, the theory divides the state aid into direct and indirect form. The direct aid means granting the beneficiary in cash. Such means could be subsidies and grants, contributions, full or partial payment of interest on the loan, repayable financial assistance provided under more favourable conditions than market conditions or increase of the capital in a way that is not in line with market conditions etc. An indirect form of assistance usually means an advantage in kind. Indirect aid is mainly state or bank guarantees provided on more favourable terms than market ones, tax relief, penalties, fines or other sanctions. It can have a form of the sale of immovable property of a state at a below the market price, and advisory services provided free of charge or as a partial reimbursement, deferment of tax payment or permission to pay tax in instalments under more favourable conditions such as market ones.

In Slovakia, the aid providers are specially stated administration bodies - the Ministry of Economy of the Slovak Republic, Ministry of Environment of the Slovak Republic and financial administration bodies tax authorities, customs offices, and science and research support agency. Assistance is provided from public funds or national, regional or local sources (Novacikova, 2016). The recipient of the aid shall be the beneficiary of a legal act entitling him to receive assistance if he simultaneously carries out an economic activity irrespective of the legal form and method of financing. Economic activity is understood as any activity consisting in offering goods or services on the market (Act No. 358/2015 Coll., § 5, par. 2). The third, usually an independent stakeholder, is the State Aid Coordinator who oversees this assistance. Its role is to eliminate cases of providing unauthorized state aid (Tetrevova et al., 2011). With effect from January 2016, the State Aid Coordinator in Slovakia is the Antimonopoly Office of the Slovak Republic (Act No. 358/2015 Coll., § 2, par. 1).

The Treaty on the Functioning of the European Union provides in $\S 107$, par. 1: «an aid granted in any form by a Member State or through state resources which distorts or threatens to distort competition by favouring certain entities or the production of certain goods is incompatible with the internal market insofar as it affects trade between Member States (Treaty on the functioning of the European Union)». As Tetrevova et al. (2011) states, this situation is usually fulfilled because there is only a small percentage of support for activities that cannot have cross-border influence. As an example, she refers to aid directed at small businesses in a region, where the impact on international trade is minimal, and the degree of localization of that entrepreneur is high.

Although public aid may distort competition, there is no absolute ban on it. Commission Regulation no. $651 / 2014$ on the declaration of specific categories of support compatible with the internal market allows the state aid exemptions for selected areas. Specifically, it is an aid for environmental protection, assistance in research, development and innovation, support for education, help for disadvantaged workers and workers with disabilities, compensation for damage caused by specified natural disasters and regional aid. The state aid could also be provided for broadband infrastructure, culture and heritage conservation, sports and multifunctional recreational activities, assistance to SMEs, local airports and ports. According to a more in-depth breakdown of the individual exemptions in the regulation, it is precisely regional aid, which covers the area of investment aid, which is the subject of our further investigation.

Regional investment aid is a form of state aid granted to businesses to support initial investment and job creation. It aims to help the development of the most disadvantaged regions and reduce existing differences between them (Balejova, 2016). Just as the state aid has its direct and indirect form, investment aid also takes on different types. According to $\S 2$ of the Investment Aid Act, assistance can be provided to support initial investment and job creation in the following models (Act No. 561/2007 Coll.):

a) subsidies on acquired tangible and intangible long-term assets;

b) income tax concessions; 
c) contribution to the nature of a new job;

d) transfer of immovable property or the letting of immovable property at a price below its value or the value of the lease determined by the expert.

Although investment aid is used to support initial investment and job creation, it does not cover all areas of business. Slovak legislation allocates precise categories of projects that are eligible for aid. Assistance is currently intended for (Ministry of economy SR, 2017):

a) industrial production;

b) technology centres;

c) enterprise service centres.

The government decisions about providing the investment incentive are affected by the specific criteria. These criteria are most often the size of the investment, the nature and significance of the investment, the investment's correspondence to the country's development programme, the number of newly created jobs, the use of domestic resources and domestic suppliers or the export performance of the investment. A fundamental criterion to be assessed is the choice of the location where the investment will take place (Vidova, 2014).

The intensity of investment aid depends on the degree of development of the Slovak regions and represents the percentage share by which the state will participate in covering the eligible costs of the investor (Fila and Kristofík, 2017). Maximum aid intensities are set out in the Government Regulation, which aligns their values with the EU-approved Regional State Aid Guidelines 2014-2020. The basis for dividing of the EU territory and the individual states was NUTS unit. For this purpose, Slovakia was divided into following NUTS II regions - the Bratislava Region, Western Slovakia, Central Slovakia and Eastern Slovakia. In these zones, the maximum aid is determined by the region's GDP per capita compared to the EU average. According to Balejova (2017), this method ensures that in less developed areas, higher investment aid intensities can be granted. The maximum power of investment aid is determined according to the size of the planned investment. For investment projects, up to $€ 50$ million is the maximum amount of investment aid intensity set in Figure 1.

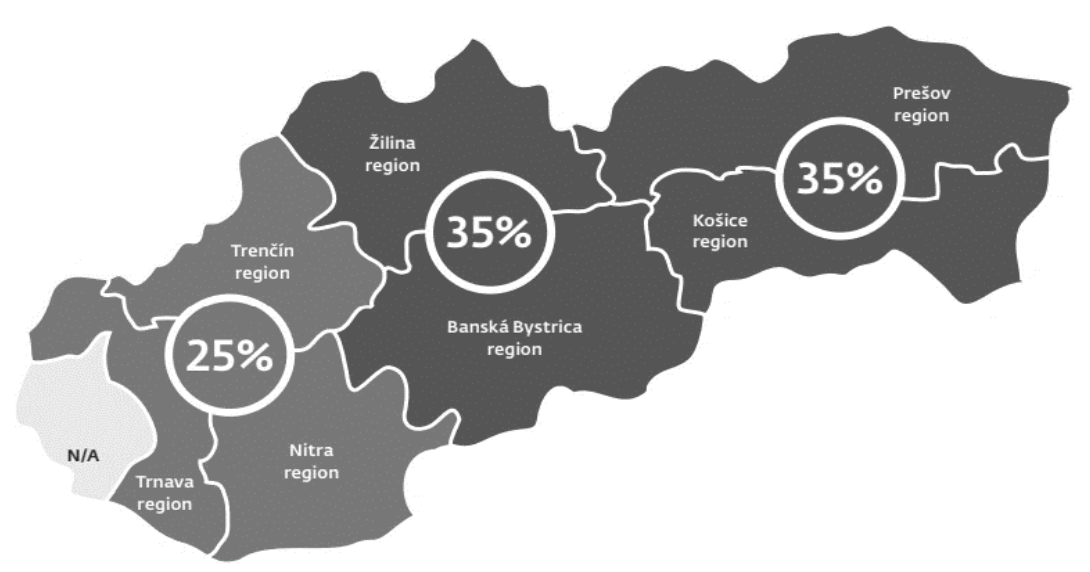

Figure 1. The maximum intensity of investment aid in Slovakia in NUTS II regions Source: SARIO, 2019. 

Investment Aid System

The Bratislava region has been excluded from the investment aid due to the high level of development. The share of investment aid provided in western Slovakia could be maximum at $25 \%$ of all eligible costs, in central and eastern Slovakia it could be up to $35 \%$.

The investment projects up to $€ 50$ million with the beneficiary were the medium-sized enterprises. The maximum intensity of the investment aid may be increased by $10 \%$ and for small enterprise even by $20 \%$.

Special conditions intend the maximum intensity for the projects with more than $€ 50$ million. The specific requirements are represented by the maximum power of investment aid and a notification obligation when the support exceeds a particular value. The maximum intensity for the investment project between $€ 50$ million and $€ 100$ million is set as the $50 \%$ of the investment aid intensity for a specific region and from the value over $€ 100$ million as the $34 \%$ of the maximum aid intensity for a particular area. The notification obligation means that Slovakia needs to request the European Commission to assess the compatibility of the proposed aid with the conditions at the stock market (Vidova, 2014).

An investor may only apply for coverage of the expenses by the investment aid if it has one of the following forms (Regional investment aid act $\S 6$ ):

a) investment costs of acquired tangible fixed assets in the type of property, plant, machinery, equipment, investment costs for acquired intangible assets in the form of industrial rights, know-how and licenses, and investment costs for renting land and building,

b) labour costs calculated as the sum of the monthly salary of employees recruited in connection with the realization of the investment, including their public health and social insurance payments and compulsory pension contributions for 24 months.

When acquiring long-term tangible assets, the purchased technologies must be new, got under market conditions and produced not earlier than two years before the acquisition (Balejova, 2015). Intangible fixed assets must be procured from other than related parties (Ministry of Economy SR, 2017). The investor has a maximum of 3 years for the project implementation (5 years for large-scale projects). In the case of job creation, the investor has a maximum of 6 years to create new job positions ( 8 years for large-scale projects). Work on the project can begin at the earliest after applying for the investment aid to the Ministry of Economy SR.

Since 2018, there has been introduced another factor influencing the maximum investment aid intensity in the Slovak Republic, the government's priority areas. Those are areas where the government wants to streamline the aid by supporting sophisticated production technologies and products with high added value. The priority areas are determining the maximum aid intensity only by the subsidies on acquired long-term assets. The priority areas do not influence the tax concessions and transfer of immovable assets. These forms of state aid need to respect only the maximum aid intensity presented in figure 1.

For each of the supported areas defined by the Investment Aid Act, minimum criteria are set, which must be fulfilled for obtaining the aid at the time of applying as well as subsequently within the implementation of the investment project (Fila and Kristofík, 2017). In connection with these criteria, investment projects can be divided into two categories according to the change of the requirements depending on the region in which the investor intends to carry out the investment project (Balejova, 2015). In Industrial Production projects, the conditions in particular areas are different. On the contrary, the requirements for the Technology Centre and Business Service Centre projects remain unchanged.

In the case of Industrial Production projects, there are conditions as the minimum investment size, share of new technological equipment ineligible costs, creation of new jobs depending on the unemployment rate in the particular region, applied form of investment aid and priority of the sectoral project specification. In the case of expansion project (by the existing enterprise), there is an obligation to increase production volume or production turnover by at least $15 \%$. 


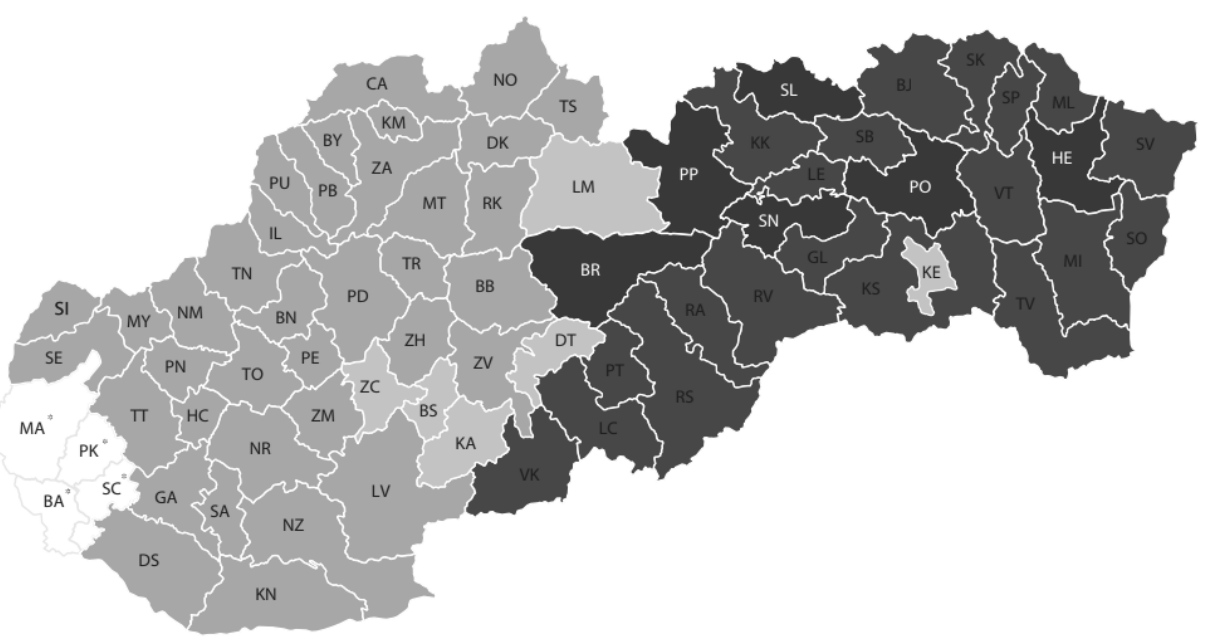

Figure 2. The categorisation of Slovak regions based on the unemployment rate (January 2019) Source: SARIO, 2019.

Figure 2 presents a division of the Slovak Republic into regions. The white colour highlights areas with an unemployment rate less than $100 \%$ of average unemployment in Slovakia (AU) - zone A. Regions with an unemployment rate between $100 \%$ and $135 \% \mathrm{AU}$ are green - zone, B. Regions with an unemployment rate of at least $135 \%$ but less than $160 \% \mathrm{AU}$, are yellow - zone C. The «Least developed regions» with an unemployment rate of at least $160 \%$ AU have red colour - zone D.

The requirements for industrial production projects are graded depending on the rate of registered unemployment in the region - see Figure 3.

\begin{tabular}{|c|c|c|c|c|c|}
\cline { 2 - 6 } \multicolumn{2}{l|}{} & $\begin{array}{c}\text { Min. investment } \\
\text { amount }\end{array}$ & $\begin{array}{c}\text { Min. investment } \\
\text { amount }\end{array}$ & $\begin{array}{c}\text { Min. investment } \\
\text { amount/ no. of } \\
\text { newly created jobs }\end{array}$ & $\begin{array}{c}\text { Min. investment } \\
\text { amount }\end{array}$ \\
\hline Zone & $\begin{array}{c}\text { Minimum share of } \\
\text { new technologies } \\
\text { on the investment }\end{array}$ & Cash grant** & Income tax relief & $\begin{array}{c}\text { Contribution for } \\
\text { newly created jobs }\end{array}$ & $\begin{array}{c}\text { Rent/sale of real } \\
\text { estate at a } \\
\text { discounted price }\end{array}$ \\
\hline A & $\mathbf{6 0 \%}$ & only priority areas & 6 mil. $€$ & n/a & 6 mil. $€$ \\
\hline B & $\mathbf{5 0 \%}$ & 30 mil. $€$ & 3 mil. $€$ & 3 mil. $€ / 200$ & 3 mil. $€$ \\
\hline C & $40 \%$ & 20 mil. $€$ & 1.5 mil. $€$ & 1.5 mil. $€ / 100$ & 1.5 mil. $€$ \\
\hline D & $\mathbf{3 0 \%}$ & 1 mil. $€$ & 0.2 mil. $€$ & 0.2 mil. $€ / 20$ & 0.2 mil. $€$ \\
\hline
\end{tabular}

Figure 3. Minimum requirements for particular aid forms in Industrial Production Source: SARIO, 2019.

At the same time, considering the form of aid, the company draws and, in the case of subsidies, it depends on whether the recipient will operate in the priority area. The criteria to be assessed are the minimum value of the investment, the minimum share of new production facilities and the number of created jobs. 
L. Hvolkova, L. Klement. Management of Innovation Development in the Slovak Republic: Critical Evaluation of the Investment Aid System

If the investment aid recipient is a small and medium-sized enterprise (SME), the minimum investment amount, and the number of newly created jobs is reduced to at least one half.

Technology centres are institutions where the development or innovation of high-tech products, technologies or production processes is carried out, and they should be used in production or to increase added value. The production process is not considered to be the activity of the Technology Centre (Regional investment aid act, §5).

\begin{tabular}{|c|c|c|c|c|c|c|}
\cline { 3 - 6 } & \multicolumn{4}{c|}{ Minimum investment amount } \\
$\begin{array}{c}\text { Project } \\
\text { sectoral } \\
\text { specification }\end{array}$ & $\begin{array}{c}\text { Min. } \\
\text { number of } \\
\text { newly } \\
\text { created jobs }\end{array}$ & $\begin{array}{c}\text { Min. fold of } \\
\text { average } \\
\text { salary in the } \\
\text { district }\end{array}$ & Cash grant & $\begin{array}{c}\text { Income tax } \\
\text { relief }\end{array}$ & $\begin{array}{c}\text { Contribution for } \\
\text { newly created } \\
\text { jobs }\end{array}$ & $\begin{array}{c}\text { Rent/sale of } \\
\text { real estate at a } \\
\text { discounted } \\
\text { price }\end{array}$ \\
\hline $\begin{array}{c}\text { Priority } \\
\text { areas }\end{array}$ & 10 & 2.0 & $200000 €$ & $100000 €$ & $100000 €$ & $100000 €$ \\
\hline Other areas & 20 & 1.7 & $400000 €$ & $200000 €$ & $200000 €$ & $200000 €$ \\
\hline
\end{tabular}

Figure 4. Minimum conditions for Technology Centres projects in Slovakia

Source: SARIO, 2019.

In the case of Technology Centre projects, there are conditions as the minimum investment size, creation of new jobs and minimum fold of average salary in the region depending on the applied form of investment aid and the priority of the sectoral project specification.

The Business Services Centre is an institution where centralized support services are provided in the areas of corporate governance, information technology, accounting, finance, legal services, control, procurement, marketing and human resources, in addition to labour renting services (Regional investment aid act, § 5).

\begin{tabular}{|c|c|c|c|c|c|c|}
\hline \multirow[b]{2}{*}{$\begin{array}{c}\text { Project } \\
\text { sectoral } \\
\text { specification }\end{array}$} & \multirow[b]{2}{*}{$\begin{array}{l}\text { Min. number } \\
\text { of newly } \\
\text { created jobs }\end{array}$} & \multirow[b]{2}{*}{$\begin{array}{l}\text { Min. fold of } \\
\text { average } \\
\text { salary in the } \\
\text { district }\end{array}$} & \multicolumn{4}{|c|}{ Minimum investment amount } \\
\hline & & & Cash grant & $\begin{array}{c}\text { Income tax } \\
\text { relief }\end{array}$ & $\begin{array}{l}\text { Contribution for } \\
\text { newly created } \\
\text { jobs }\end{array}$ & $\begin{array}{l}\text { Rent/sale of } \\
\text { real estate at a } \\
\text { discounted } \\
\text { price }\end{array}$ \\
\hline $\begin{array}{l}\text { Priority } \\
\text { areas }\end{array}$ & 20 & 1.8 & $200000 €$ & $0 €$ & $0 €$ & $0 €$ \\
\hline Other areas & 50 & 1.5 & $\mathrm{n} / \mathrm{a}$ & $0 €$ & $0 €$ & $0 €$ \\
\hline
\end{tabular}

Figure 5. Minimum conditions for business service centres projects in Slovakia Source: SARIO, 2019.

In the case of Business Service Centres projects, there are conditions for the receiving of Investment aid as the minimum investment size, creation of new jobs and minimum fold of average salary in the region depending on the applied form of investment aid and the priority of the sectoral project specification.

Depending on the level of conditions set, it is still true that the difficulty of all requirements decreases with the transition to a zone of regions with higher unemployment. However, the new Regional investment aid act has brought a change in the abandonment of job creation, which is no longer a prerequisite. Job places must be created if the company asks for the contribution to new jobs. Similarly, the requirement of a minimum value of the investment coverage by equity was waived. Unlike the previous amendment, 

Investment Aid System

according to which the elements were graded only by region unemployment, the Government regulation defines special conditions for each form of investment aid.

Methodology and research methods. Regional investment aid (further also investment aid) is considered and presented as a tool supporting investments and job creation, which is intended to help to notably less developed regions in Slovakia and thus reduce existing regional disparities. Following this logic, the paper focuses on examining whether investment aid in Slovakia has served its purpose and was channelled mainly to less developed regions.

In order to fulfil the aim of the paper, the authors have set out next research questions:

1. Was the regional investment aid allocated to the projects proportionally during the analysed period 2002-2018 according to the amount of investment aid?

2. Are there differences in investment aid costs for one newly created job in Slovak regions?

3. Has the investment aid been targeted to the less developed areas?

The data on business entities, which have been granted by the investment aid, was obtained from the Ministry of Economy of the Slovak Republic. The period 2002-2018 is analysed, in case of 2018 considering only first two months - January and February. Another source of information were data from the Statistical Office of the Slovak Republic using information about the level of development of particular Slovak regions. Two indicators have been selected for the analysis - the rate of unemployment and GDP per capita. Both indexes were calculated in the form of average from period 2002-2017, in further investigation, the average rate of unemployment in particular Slovak districts in individual years of the analysed period was used. Descriptive statistics and comparison explained the obtained data to evaluate the total provided investment aid. The contribution of the article lies in the evaluation of the effectiveness of the investment aid and the fulfilment of the aim of the investment aid presented in Slovak legislation to support less developed Slovak regions to reduce regional disparities.

Results. Investment aid to support the development of the most disadvantaged regions is provided from 2002. During this period, the legislation covering this topic has changed a few times. Moreover, also the level of the economy and standard of living in particular Slovak regions have turned. The total amount of investment aid in this period has reached to almost $€ 1.75$ billion to support 197 investment projects. As the number of total costs of sponsored projects was more than $€ 8.4$ billion in the period 2002-2018, the investment aid covered approximately $20 \%$ of these costs. Investment aid was granted to 162 subjects from 28 different countries, including Slovakia. The recipients have promised to create more than 58 thousand jobs in Slovakia.

The number of recipients (162) is different compared to the number of projects (197) as 32 enterprises have obtained repeated aid. The most frequent field of the economy that has been supported was the automotive industry with 81 recommended investments. Investment aid can be obtained by each enterprise that fulfils the conditions according to the Slovak legislation with the primary intention to realize the project in the Slovak Republic. Therefore, nationality is not a criterion that can decide whether the project will be supported or not and state aid is designed for domestic and foreign companies. According to our analysis, $85 \%$ of the total number of sponsored projects were international companies that have planned to create more than 53 thousand of new jobs. From the funding point of view, the difference between Slovak and foreign recipients is more significant, as only $7 \%$ of the total financial resources were granted to the Slovak companies. This state also means the fact that investment aid in the Slovak Republic represents a powerful support mechanism for the establishment of foreign investors in Slovakia. The infusion of the foreign direct investments is very often connected with the development of regions as it can represent essential impulse for its economic growth.

The level of the provided investment aid was, in particular years, quite different. The evaluated period is analysed in the next table through the number of supported projects, the number of planned newly created jobs and the total amount of provided investment aid in particular years. 
L. Hvolkova, L. Klement. Management of Innovation Development in the Slovak Republic: Critical Evaluation of the Investment Aid System

Table 1. Investment aid during period 2002-2018

\begin{tabular}{|c|c|c|c|}
\hline Year & Number of projects & Number of planned jobs & Amount of investment aid $(€)$ \\
\hline 2002 & 1 & 582 & 12746465 \\
\hline 2003 & 1 & 3500 & 166018388 \\
\hline 2004 & 18 & 8880 & 313402342 \\
\hline 2005 & - & - & - \\
\hline 2006 & 48 & 15385 & 358314808 \\
\hline 2007 & 16 & 6113 & 190038092 \\
\hline 2008 & 5 & 2199 & 42667673 \\
\hline 2009 & 8 & 2976 & 75270583 \\
\hline 2010 & 11 & 1350 & 39067024 \\
\hline 2011 & 10 & 2120 & 64930195 \\
\hline 2012 & 10 & 2412 & 121191498 \\
\hline 2013 & 11 & 2459 & 60853168 \\
\hline 2014 & 13 & 1630 & 99887481 \\
\hline 2015 & 16 & 2485 & 49648372 \\
\hline 2016 & 8 & 2487 & 59162000 \\
\hline 2017 & 15 & 3056 & 83945520 \\
\hline 2018 & 6 & 1172 & 10812282 \\
\hline Total & 197 & 58806 & 1747955891 \\
\hline
\end{tabular}

Source: own processing from the database of the Ministry of Economy SR.

The level of investment aid was changing during the evaluated period; some changes were more radical; others were smaller. The period 2004-2006 was very variable, as in 2005 none project was supported through this type of state support. On the other hand, in 2006, the highest number of projects was endorsed with the highest amount of money in the analysed period, and 2004 was the second most successful year considering the number of projects and amount of the aid. Supported projects in 2004 and 2006 took together $34 \%$ of the total number of supported projects, while the amount of the provided aid took $38 \%$ of the total amount of granted money. Investment aid is supporting projects and ideas of enterprises through various forms, and the combination of two or more types of investment aid is possible. There are four primary forms of investment aid provided for the investors until 2006 there was also the possibility to obtain the grant for the employee's requalification (cancelled in 2006). Utilization of particular forms of investment aid in Slovakia was analysed according to the share of the total amount of the supported projects and the amount of the money (Table 2).

Table 2. Utilization of particular forms of investment aid

\begin{tabular}{|l|c|c|}
\hline Forms of investment aid & $\begin{array}{c}\text { Number of } \\
\text { supported projects }\end{array}$ & $\begin{array}{c}\text { Amount of } \\
\text { investment aid }(€)\end{array}$ \\
\hline Income tax concession & 169 & 845325144 \\
\hline $\begin{array}{l}\text { Subsidy on acquired tangible and intangible long- } \\
\text { term assets }\end{array}$ & 85 & 683066321 \\
\hline Contribution to the creation of new jobs & 66 & 120356634 \\
\hline Grant for requalification & 32 & 52512165 \\
\hline $\begin{array}{l}\text { Transfer of immovable property at a price below its } \\
\text { value }\end{array}$ & 2 & 46695630 \\
\hline
\end{tabular}

Source: own processing from the database of the Ministry of Economy SR. 

Investment Aid System

The most common form of investment aid was income tax concession. It was granted 169 times, which means that almost $86 \%$ of the projects were supported in the total sum of more than $€ 845$ million. Subsidies on acquired tangible and intangible long-term assets were granted 85 times ( $45 \%$ of projects) in the amount of more than $€ 683$ million. Contribution to the creation of new jobs was awarded to 66 projects and covered almost $34 \%$ of all investments. The grant for requalification has supported 32 projects (more than 16\%), which is a considerable number as it was provided for only five years. Considering income tax concessions as the most common form of investment aid it is necessary to emphasize that enterprises obtain this form of state support not only in one year in the way of a grant but usually during several years as the real utilization of this aid occurs only by a tax duty of the enterprise. As the duration of providing this form is generally different in particular enterprises, it was ascribed in the year when it was promised to the recipients.

As investment aid is derived from the national budget, so it is essential to analyse how and where it was allocated and if it has supported the development of the less developed parts of Slovakia. First and straightforward indicator can be the division of the granted investment aid to the Slovak regions. According to the data about the level of development, the west part of Slovakia is considered the most developed part of our country. Regarding the division of investment aid in the regions of Slovakia, there are considerable differences. More than half $(51.20 \%)$ of the financial resources were allocated for the west of Slovakia in the value of more than $€ 894$ million. Eastern Slovak regions are less developed compared with the rest of Slovakia. However, less than $20 \%$ of all financial resources (approximately $€ 344$ million) were allocated here and almost $30 \%$ to the middle part of Slovakia. From this point of view, the goal of investment aid to support less developed regions was not fulfilled.

More detailed analysis, considering the level of development with the utilization of indicators of the average rate of unemployment and GDP per capita (both signs valid for period 2002-2017), was performed in the next step.

Table 3. Comparison of the development of Slovak regions with the amount of investment aid

\begin{tabular}{|l|c|r|r|}
\hline Region & $\begin{array}{c}\text { The average rate of } \\
\text { unemployment }(\%)\end{array}$ & $\begin{array}{c}\text { Average GDP per } \\
\text { capita }(€)\end{array}$ & $\begin{array}{c}\text { Amount of investment } \\
\text { aid }(€)\end{array}$ \\
\hline Bratislava region & 4.19 & 28551 & 62779914 \\
\hline Trnava region & 7.47 & 13197 & 375784981 \\
\hline Trencín region & 8.01 & 10572 & 204132951 \\
\hline Nitra region & 11.60 & 10295 & 252195557 \\
\hline Zilina region & 9.85 & 10140 & 362933261 \\
\hline Banska Bystrica region & 17.46 & 8867 & 145756682 \\
\hline Presov region & 16.62 & 7016 & 81743658 \\
\hline Kosice region & 16.70 & 9717 & 262628887 \\
\hline
\end{tabular}

Source: own processing from the database of the Ministry of Economy SR and the Statistical Office of the Slovak Republic.

According to the rate of unemployment and GDP per capita, it can be confirmed that the least developed regions were Banska Bystrica, Presov and Kosice. The analysis of the amount of investment aid provided to the Slovak regions has identified that Trnava region with the second-lowest average rate of unemployment $(7.47 \%$ ) and second-highest average GDP per capita ( $€ 13197)$ has obtained the highest amount of investment aid (21.5\% from the total amount). Moreover, almost other $21 \%$ of the amount of investment aid was allocated for Zilina region, which cannot be considered to be a less developed region of Slovakia. According to the analysis, the connection between the higher amount of investment aid and the less developed area was confirmed only in the Kosice region. Therefore, the share of $15 \%$ of the total 

Investment Aid System

amount of investment aid can be valid as a responsible expense used for support of the less developed region. From this point of view, the aim of investment aid to support the least developed areas was not fulfilled.

In the next step, the authors have analysed how costly were the newly created jobs in Slovak regions according to the amount of provided investment aid and the number of planned freshly created posts (Table 4). The total amount of investment aid considering all various forms of investment aid was used because the commitment to create new jobs is not connected only with obtaining of the contribution to the creation of new posts but all forms of investment aid.

Table 4. Costs for one newly created job in Slovak regions

\begin{tabular}{|l|c|c|c|c|}
\hline \multicolumn{1}{|c|}{ Region } & $\begin{array}{c}\text { Amount of } \\
\text { nvestment aid }(€)\end{array}$ & $\begin{array}{c}\text { Planned newly } \\
\text { created jobs }\end{array}$ & $\begin{array}{c}\text { Prices for 1 freshly } \\
\text { created position }(€)\end{array}$ & $\begin{array}{c}\text { Ranking according to } \\
\text { the new job costs }\end{array}$ \\
\hline Bratislava region & 62779914 & 3399 & 18470 & 7. \\
\hline Trnava region & 375784981 & 7628 & 49264 & 2. \\
\hline Trencín region & 204132951 & 11396 & 17913 & 8. \\
\hline Nitra region & 252195557 & 8930 & 28241 & 4. \\
\hline Zilina region & 362933261 & 6867 & 52852 & 6. \\
\hline Banska Bystrica region & 145756682 & 6989 & 20855 & 3. \\
\hline Presov region & 81743658 & 2682 & 30479 & 5. \\
\hline Kosice region & 262628887 & 10915 & 24061 & - \\
\hline Total & 1747955891 & 58806 & 29724 & \\
\hline
\end{tabular}

Source: own processing from the database of the Ministry of Economy SR.

As it was already mentioned, the investors have promised to create more than 58 thousand of new jobs during the period 2002-2018. According to the analysis, there were differences between regions based on this criterion. Especially high costs seem to be allocated to the Zilina region with the second-highest share on the investment aid. Still, considering the number of newly created jobs, this region was only in 6 th place. Therefore, in this region, there have been invested the highest financial resources for one freshly created position in the average amount of more than $€ 52$ thousand. The second highest costs were identified in the Trnava region (almost $€ 50$ thousand on average) due to the most upper support in investment aid and relatively low number of newly created jobs (4th place). Presov region was identified as the region with the third-highest costs for the newly created position; on the other hand, according to our analysis, it is a less developed region. Therefore, these costs can be acceptable. The lowest average values for one newly created job were calculated for Bratislava and Trencín region. Areas that have obtained the highest amount of investment aid were also identified as those with the highest costs for one newly created job. On the other hand, regions with the lowest prices for the newly created position were those with a smaller share of investment aid.

The effectiveness of investment aid can also be investigated through the relationship between the number of financial resources in Slovak regions. For this purpose, the authors have used the classification of Slovak districts into two groups - those with a lower and higher rate of unemployment than the average rate of unemployment in a particular year. The effectiveness was compared through the amount of investment aid and the number of newly created jobs. During the analysed period (2002-2018), the investment aid was approved for 51 different districts (65\% from the total number of areas in Slovakia) in the amount of more than $€ 1.7$ billion. The reallocation of investment aid in particular districts during the analysed period presents the next figure. 

Investment Aid System

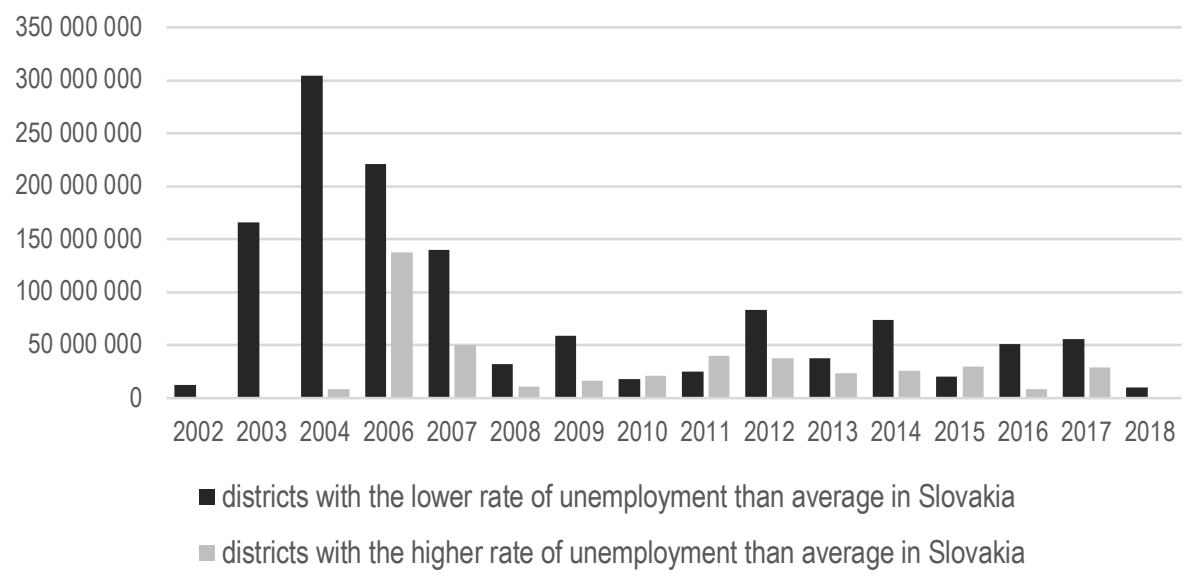

6. Investment aid in Slovak districts in 2002-2018

Figure

Source: own processing from the database of the Ministry of Economy and the Statistical Office of the Slovak Republic.

According to the results, the trend of prioritization of developed districts is noticeable. In almost threequarters of the analysed period ( 13 years), the investment aid was provided for investors with localization in areas with a lower rate of unemployment than was the average in Slovakia. In 2004, there was evidence of the second-highest amount of investment aid aimed mostly at highly developed districts; less developed areas have obtained less than 3\%. Only in three years - 2010, 2011 and 2015, there was a higher amount of investment aid oriented at districts with a higher unemployment rate than the average in Slovakia.

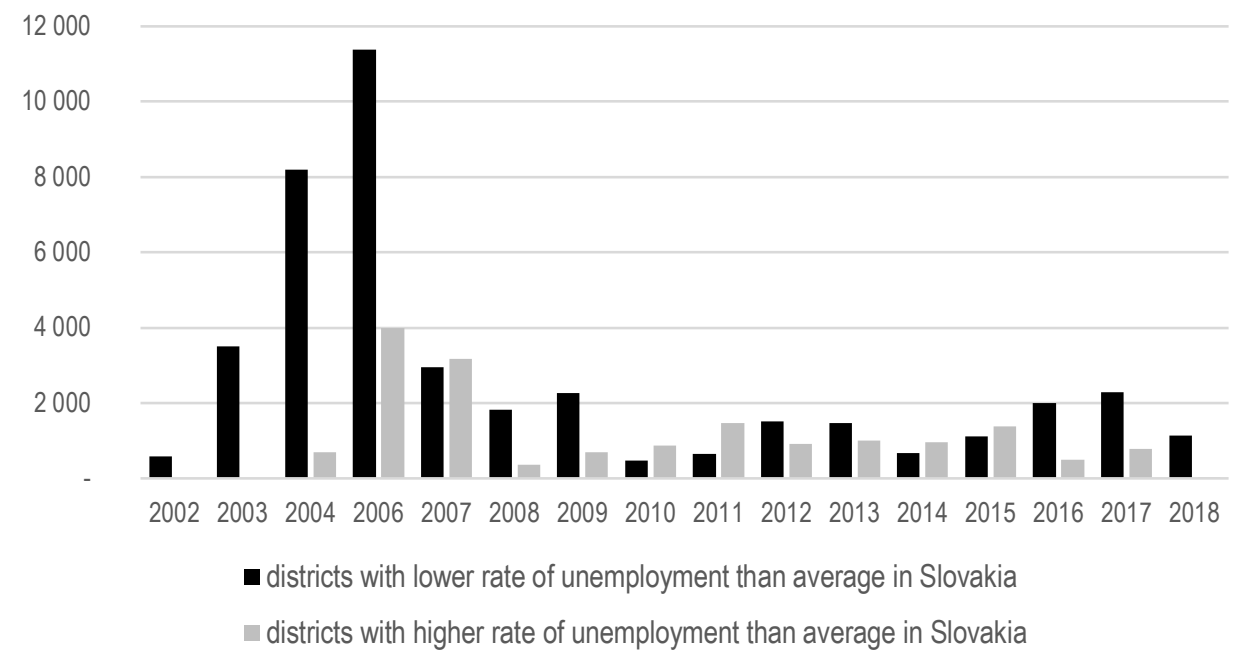

Figure 7. Planned creation of new jobs in Slovak districts in 2002-2018

Source: own processing from the database of the Ministry of Economy and the Statistical Office of the Slovak Republic. 
L. Hvolkova, L. Klement. Management of Innovation Development in the Slovak Republic: Critical Evaluation of the Investment Aid System

Strong potential for the change on the allocation of investment aid brings the comparison of the support in the field of creation of new jobs. However, considering the findings, this fact was not supported. The support of developed districts in the area of the nature of new posts was higher, compared to the aid of less developed regions, during 11 years from the period 2002-2018, that were almost two-thirds from this period. During 2002 and 2003, the state has supported the creation of new jobs only in developed districts, the highest absolute differences in amount and number of sponsored projects were in 2004 and 2006. On the other hand, the superiority of the creation of new jobs in less developed districts was identified in five years. Still, approximately, the differences were not so noticeable. In 2011 the number of posts in less developed areas were $120 \%$ higher than in developed districts, 2010 was the second most successful year, but the number of jobs was higher only in $80 \%$.

Conclusions. Regional investment aid represents a secure tool of support for enterprises and their domestic and foreign initial investments. According to the Slovak legislation aimed at this area - the necessary regulation is covered by the Act No. 57/2018 Coll. on regional investment aid - the main aim of investment aid is to support the most disadvantaged regions and reduce existing disparities between them. These problems can be solved with the help of the creation of new jobs, building infrastructure and networking with enterprises on the local level. The Slovak government has defined specific conditions for enterprises to obtain investment aid considering the forms of investment aid, categories of projects that are eligible for funding, the intensity of investment aid and other requirements.

The main aim of this paper was to examine if the investment aid in Slovakia has served its purpose and was channelled mainly to disadvantaged regions in the period 2002-2018. Following the aim of the paper, three research questions were formulated. The first research question was dedicated to the proportion of provided investment aid in time and amount. In years 2004 and 2006, there was the relatively high share of supported projects $(33.5 \%$ from all) that took a considerably large portion from the total amount of allocated financial resources (3\%) with the plan to create 24265 new jobs (41.26\%). It took the next seven years (2007-2013) to support $36 \%$ of all projects with the creation of $33.37 \%$ from all new jobs. During the next five years (2014-2018), there were supported $29.44 \%$ of all projects that have promised to create 10830 new jobs from total 58806 new posts (18.41\%) in value of $€ 303455655$ from the total amount of $€ 1747955891$ (17.36\%). According to the results of the analysis based on secondary data from the Ministry of Economy SR and the Statistical Office of the Slovak Republic, there were evident differences in particular years according to the total amount of investment aid.

As the regional investment aid is provided from public funds, evaluation of aid effectiveness through the calculation of costs for one newly created job seems to be an appropriate indicator. According to this fact, the prices for one freshly created position in particular Slovak regions were quite different, the average varied from $€ 17913$ (Trencín region) to $€ 52852$ (Zilina region). As the second research question was answered positively, it can be concluded that this aspect should be taken into consideration more in future decisions. Connected with the third research question, Table 5 presents the effectiveness of provided investment aid with the help of the summary value of selected indicators.

Table 5. Share of districts on the summary value of indicators of investment aid

\begin{tabular}{|l|c|c|}
\hline & $\begin{array}{c}\text { Districts with a lower rate of } \\
\text { unemployment }\end{array}$ & $\begin{array}{c}\text { Regions with a higher rate } \\
\text { of unemployment }\end{array}$ \\
\hline Number of projects & $56 \%$ & $44 \%$ \\
\hline Amount of investment aid & $75 \%$ & $25 \%$ \\
\hline Number of created jobs & $71 \%$ & $29 \%$ \\
\hline
\end{tabular}

Source: own processing from the database of the Ministry of Economy SR. 
During the analysed period, 110 investments were realised in regions with a lower rate of unemployment compared to the average price in Slovakia that comprised the share of $56 \%$ of the total number of projects. The aid in these regions was realised with the sum of more than $€ 1.3$ billion, that was $75 \%$ of the total amount of investment aid. The analysis confirmed that investment aid in Slovakia is still not focused on the support of less developed regions.

This study has some limitations; first, the effectiveness of investment aid is a broader term. The analysis of average costs for one newly created job in Slovak regions provides the necessary information. Still, essential is also to identify the type of new positions (workers or highly qualified personnel). Secondly, the form of investment aid also matters. The tax concessions provided to recipients did not need any government expenses in the period when it was granted. Still, in further years (in case of tax duty of enterprise), the state budget incomes are reduced.

On the other hand, subsidies on long-term assets or contributions to the creation of new jobs are connected with immediate government expenses. Moreover, the level of development of Slovak regions can be analysed with the help of other indicators not only the rate of unemployment and GDP per capita but also symbols such as the impact of investment aid on revenues, costs, added value etc. Establishment of a new company/investor in the region can also generate new companies in the position of subcontractors or partners with additional impact on regional development.

Author Contributions: The outline of the paper was prepared by L. H., L. K. and L. H.; wrote abstract, L. K.; developed theoretical background and literature review, L. H.; provided data and prepared methodology, L. H.; performed the analysis and visualization of results, L. K. and L. H.; wrote discussion, L. K.; was responsible for references control.

\section{References}

Act no. 561/2007 Coll. on Investment aid (Slovakia).

Act no. 358/2015 Coll. on State aid (Slovakia).

Act no. 57/2018 Coll. on Regional investment aid (Slovakia).

Balejova, M. (2015). Podpora priamych zahranicnych investícii v Slovenskej republike - analyza investicnej pomoci. Medzinarodne vztahy 2015: aktualne otazky svetovej ekonomiky a politiky. Bratislava: Vydavatestvo EKONOM. Retrieved April 24, 2019. Retrieved from: https://fmv.euba.sk/www write/files/dokumenty/veda-vyskum/konferencie/zborniky/Virt_2015.pdf

Balejova, M. (2016). Osobitosti lakania priamych zahranicnych investícií v krajinach V4 po vstupe do Europskej unie. Ekonomicke, politicke a pravne otazky medzinarodnych vztahov 2016: Zbornik vedeckych prac. Bratislava: Vydavatelstvo EKONOM. Retrieved April 25, 2019. Retrieved from: https://fmv.euba.sk/www write/files/veda-vyskum/konferencie-virt/2015/Almanach.pdf

Balejova, M. (2017). Investicna pomoc v Slovenskej Republike: Nastroj na podporu okresov s vysokou nezamestnanostou? Ekonomicke, politicke a pravne otazky medzinarodnych vztahov 2017: Zborník vedeckych prac. Bratislava: Vydavatelstvo EKONOM. Retrieved April 25, 2019. Retrieved from: https://fmv.euba.sk/www write/files/veda-vyskum/konferencievirt/2017/zborn\%C3\%ADk_Virt_2017.pdf

Commission regulation no. 651/2014 declaring certain categories of aid compatible with the internal market in application of Articles 107 and 108 of the Treaty. Retrieved May 25, 2019, from: https://eur-lex.europa.eu/legalcontent/EN/TXT/PDF/?uri=CELEX:32014R0651\&from=EN

Collie, D. R. (2005). State Aid to Investment and R\&D. Economic papers. Brussel: Belgium. Retrieved May 8, 2019. Retrieved from: http://ec.europa.eu/economy finance/publications/pages/publication616 en.pdf

Fila, M., \& Kristofík, P. (2017). Investicna pomoc ako nastroj externeho spolufinancovania investicnych projektov v podnikoch na Slovensku. Financny manaZer: Periodikum Slovenskej asociacie podnikovych financníkov, 17 (3): 6-12. Retrieved February 20, 2019, from: http://asocfin.sk/wp-content/uploads/2012/07/FM-3-2017.pdf

Friederiszick, H.W., Roller, L.H., \& Verouden, V. (2006). European State Aid control: an economic framework. Handbook of Antitrust Economics, 625-669. [Google Scholar]

Government Regulation setting the conditions for granting of investment aid, the maximum investment aid intensity and the maximum amount of investment aid in the regions of the Slovak Republic. Retrieved May 20, 2019. Retrieved from: https://www.slovlex.sk/legislativne-procesy/SK/LP/2018/181

Holscher, J., Nulsch, N., \& Stephan, J. (2017). State Aid in the New EU Member States. JCMS: Journal of Common Market Studies, 554), 779 - 797. [Google Scholar] [CrossRef] 
L. Hvolkova, L. Klement. Management of Innovation Development in the Slovak Republic: Critical Evaluation of the Investment Aid System

Ministry of economy SR (2019, May 20). Zoznam subjektov, ktorym bolo schvalene poskytnutie investicnej pomoci. Retrieved from: http://www.economy.gov.sk/uploads/files/KC8g9mtl.xlsx

Ministry of Economy SR (2017). Regionalna investicna pomoc: Zakladne informacie. Retrieved April 25, 2019. Retrieved from: http://www.economy.gov.sk/uploads/files/aihLEU1A.pdf

Mynarzova, M. (2014). Verejna podpora podniku prizmatem novych pravidel verejne podpory Evropske unie. Trendy v podnikaní 2014: Recenzovany sbornik prispevku mezinarodni vedecke konference. Plzen, 13-14. November 2014. Retrieved February 20, 2019. Retrieved from: https://www.tvp.zcu.cz/cd/2014/PDF sbornik/mynarzova.pdf

Novacikova, D. (2016). Institucionalna zmena v oblasti politiky statnej pomoci na Slovensku. Europska ekonomicka integracia v kontexte aktualneho vyvoja a vyziev pre clenske staty Europskej unie: Zbornik vedeckych príspevkov. Praha: Wolters Kluwer. Retrieved May 19, 2019. Retrieved from: https://www.fm.uniba.sk/fileadmin/fm/Veda/Forum bilateralne/zbornik-eu-ekonomickaintegracia v3.pdf

SARIO. (2019, April 25). Investment aid in Slovakia. Retrieved from: https://www.sario.sk/en/invest-slovakia/supportinvestors/regional-investment-aid

Tetrevova, L. et al. (2011). Verejny a podnikatelsky sektor. Pribram: Professional Publishing.

Treaty on the functioning of the European Union. (2019, May 18). Retrieved from https:/leur-lex.europa.eu/legalcontent/EN/TXT/PDF/?uri=CELEX:12012E/TXT\&from=EN

Vidova, J. (2014). Investicne stimuly ako vyznamny zdroj financovania investicnych projektov v Slovenskej republike. [Google Scholar]

Ленка Хволков, Ph.D., доцент, Університет Матея Бела (Словаччина):

Ладіслав Клемент, Ph.D., доцент, Університет Матея Бела (Словаччина).

Досвід Словаччини в управлінні інноваційним розвитком підприємств: оцінювання системи інвестиційної підтримки

Систему державної інвестиційної підтримки інноваційного розвитку підприємств Словацької Республіки запроваджено у 2002 році. При цьому у березні 2008 року значні розриви економічного розвитку між Словацькими регіонами обумовили їі модернізацію. Основною метою статті $\epsilon$ аналіз результатів впровадження системи державної інвестиційної підтримки інноваційного розвитку підприємств у Словацькій республіці. Обєктом дослідження обрано інвестиційні проекти, що отримали відповідну державну інвестиційну підтримку у 2002-2018 роках. При цьому суб'єктами дослідження обрано окремі інструменти інвестиційної підтримки інноваційного розвитку підприємств у Словацькій республіці. Для досягнення поставленої мети, у статті проаналізовано об'єм та структуру інвестиційної підтримки інноваційного розвитку підприємств у Словацькій республіці. Вихідні данні для дослідження сформовано на основі вторинних даних Міністерства економіки Словацької республіки, що представлені у вигляді бази даних суб'єктів господарювання, яким надано інвестиційну допомогу. Дані про рівень безробіття та ВВП на душу населення у регіонах Словацької республіки отримано зі Статистичного офісу Словацької республіки. Аналіз панельних даних здійснено за допомогою методів описової статистики та порівняння, що дозволило оцінити обсяги наданої інвестиційної підтримки на інноваційний розвиток підприємств. Авторами проведено аналіз у наступній логічній послідовності:1) аналіз рівномірності розподілу інвестиційної допомоги протягом 2002-2018 років; 2) оцінювання пропорційності покритих витрат до новостворених робочих місць; 3) перевірка відповідності цільового призначення інвестиційної допомоги та аналіз зміни регіональної нерівності (на основі розподілу інвестиційної допомоги за регіонами Словацької республіки). Отримані результати дослідження свідчать про наявні значні розриви у загальній сумі наданої інвестиційної допомоги за досліджуваний період. Авторами визначено, що витрати на створення робочих місць залежали від регіону Словацької республіки. Встановлено, що у певних регіонах вартість створення нових робочих місць у три рази вища, порівняно з іншими регіонами. Авторами зазначено, що 75\% загального об'єму інвестиційної допомоги надано саме регіонам з низьким рівнем безробіття. За результатами дослідження встановлено, що Словацька система інвестиційної підтримки інноваційного розвитку підприємств потребує подальшого удосконалення та впровадження інноваційних підходів із метою спрямування інвестицій на підтримку менш розвинутих регіонів країни.

Ключові слова: інвестиційна допомога, Словацька республіка, державна підтримка, регіони, рівень безробіття.

Manuscript received: 28.09.2019.

(C) The author(s) 2020. This article is published with open access at Sumy State University. 